\title{
Synthesis of new fluorescent molecules having an aggregation-induced emission property derived from 4-fluoroisoxazoles
}

\author{
Kazuyuki Sato , Akira Kawasaki, Yukiko Karuo, Atsushi Tarui, Kentaro Kawai \\ and Masaaki Omote*
}

\section{Full Research Paper}

\section{Address:}

Faculty of Pharmaceutical Sciences, Setsunan University, 45-1

Nagaotoge-cho, Hirakata, Osaka 573-0101, Japan

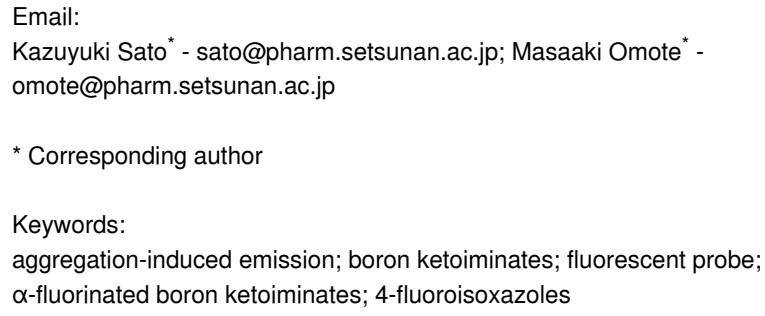

\author{
Beilstein J. Org. Chem. 2020, 16, 1411-1417. \\ doi:10.3762/bjoc.16.117 \\ Received: 27 March 2020 \\ Accepted: 09 June 2020 \\ Published: 22 June 2020 \\ Associate Editor: I. Baxendale \\ (C) 2020 Sato et al.; licensee Beilstein-Institut. \\ License and terms: see end of document.
}

\begin{abstract}
Fluorescent molecules based on a fluorinated isoxazole scaffold were synthesized and investigated for their photochemical properties. The introduction of a fluorine substituent into 3,5-diarylisoxazoles led to an increase of fluorescence intensity and exhibited a redshift in the emission intensity. $\alpha$-Fluorinated boron ketoiminates (F-BKIs) were also synthesized via a ring-opening reaction of 4-fluoroisoxazoles and exhibited highly fluorescent luminescence and aggregation-induced emission (AIE), showing promise as a new fluorophore.
\end{abstract}

\section{Introduction}

Fluorescence bioprobes based on conventional organic dyes are used for enzyme activity measurements and in bioimaging systems with promising applications in the field of clinical diagnostics [1-7]. Most of the fluorescence bioprobes are mainly excited with near-ultraviolet or blue light ray and the structures often include fluorescein, rhodamine, or 7-amino-4-methylcoumarin (7-AMC) scaffolds as fluorophores. These fluorophores usually exhibit strong fluorescence in dilute solutions, but most of their emissions are partially or completely quenched in the solid state or in highly concentrated solutions by aggrega- tion-caused quenching (ACQ) [8]. On the other hand, there are molecules that exhibit strong emission even in poor solvents or in the solid state. This property is referred to as aggregation-induced emission (AIE) and has attracted much attention in the field of fluorescence bioprobes [9-14]. For example, it is presumed that prion disease, which is caused by the accumulation of prion protein aggregates in the brain, plays an important role in the pathophysiological mechanism of prion protein-polymerized oligomers. However, since prion protein oligomers cannot be visualized using fluorescent probes, the use of AIE 
fluorescent probes is being investigated as a tool for analyzing the causal relationship between prion diseases and prion proteins.

The importance of fluorinated heterocyclic derivatives in the pharmaceutical and agrochemical industries continues to grow, with several fluorinated 6-membered heteroaromatic derivatives finding applications in a wide variety of drugs and plantprotective agents [15-27]. However, there are only a few reports on the synthesis and properties of fluorinated 5-membered heteroaromatic systems, especially those comprising two heteroatoms such as pyrazoles [28,29], isoxazoles [30], and thiazoles [31,32]. Recently, we reported the selective fluorination of isoxazoles, to give monofluorinated isoxazoles $\mathbf{3}$ or trifluorinated isoxazolines $\mathbf{4}$ in moderate to good yields (Scheme 1) [33]. In addition, we reported that the reaction proceeded smoothly by starting with 1,3-diketones (1) to give $\mathbf{3}$ in excellent yields in a one-pot reaction.

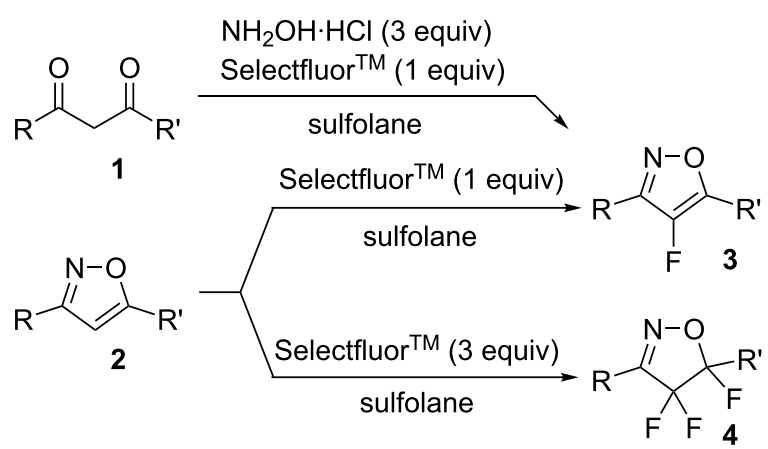

Scheme 1: Selective fluorination of isoxazoles and one-pot synthesis of 4-fluoroisoxazoles.
As part of a wider research program aimed at the applications of fluorinated 5-membered heteroaromatic systems, in this paper, we report the fluorescent luminescence characteristics of 4-fluoroisoxazoles, the synthesis of $\alpha$-fluorinated boron ketoiminates (F-BKIs), and their photochemical properties.

\section{Results and Discussion Synthesis and optical properties of 4-fluorinated isoxazoles}

Although there is a large number of fluorescent molecules, fluorescent probes having an isoxazole scaffold are rare and the limited examples that are available also contain other fluorophores such as styryl, anthranyl, or pyrenyl groups in the molecules. We recently reported the synthesis of 3,5-diaryl-4-fluoroisoxazoles $\mathbf{3}$ that were found to have planar structures suggesting that they might have the potential to act as a fluorophore [33]. During the synthesis of 3,5-diaryl 4-fluoroisoxazoles 3 according to the previous method (Scheme 2), we noted that 3,5-bis(4-methoxyphenyl)-4-fluoroisoxazole (3b) and 3,5bis(4-trifluoromethylphenyl)-4-fluoroisoxazole (3c) exhibited fluorescent properties by irradiation with a UV lamp.

Among the non-fluorinated isoxazoles, only $\mathbf{2 c}$ demonstrated fluorescent emission, although it was very weak. Thus, we decided to further investigate the photochemical properties and the results were summarized in Figure 1 and Table 1. Introducing a fluorine substituent into the isoxazole scaffold led to an increasing fluorescent intensity and exhibited a redshift in the emission intensity. Interestingly, the excitation maximum of 3 showed a redshift of approximately $20 \mathrm{~nm}$ with the incorporation of a single fluorine atom into the isoxazole scaffold in com-

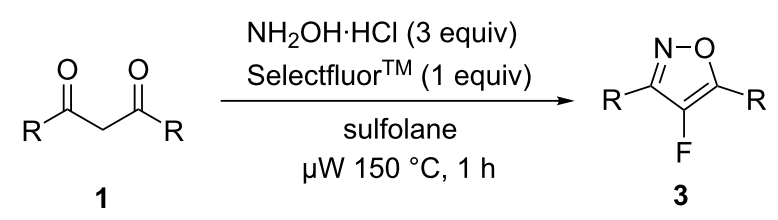

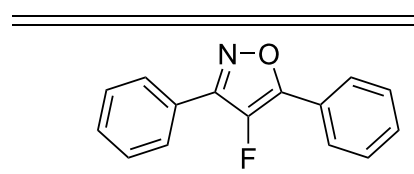

3a, $91 \%^{\mathrm{a}}(90 \%)^{\mathrm{b}}$<smiles>Fc1c(-c2ccc(C(F)(F)F)cc2)noc1-c1ccc(C(F)(F)F)cc1</smiles>

$3 c, 86 \%^{a}$<smiles>COc1ccc(-c2noc(-c3ccc(OC)cc3)c2F)cc1</smiles>

3b, $83 \%^{a}$<smiles>Fc1c(-c2cccc(C(F)(F)F)c2)noc1-c1cccc(C(F)(F)F)c1</smiles>

3d, $48 \%^{\mathrm{a}}$ 

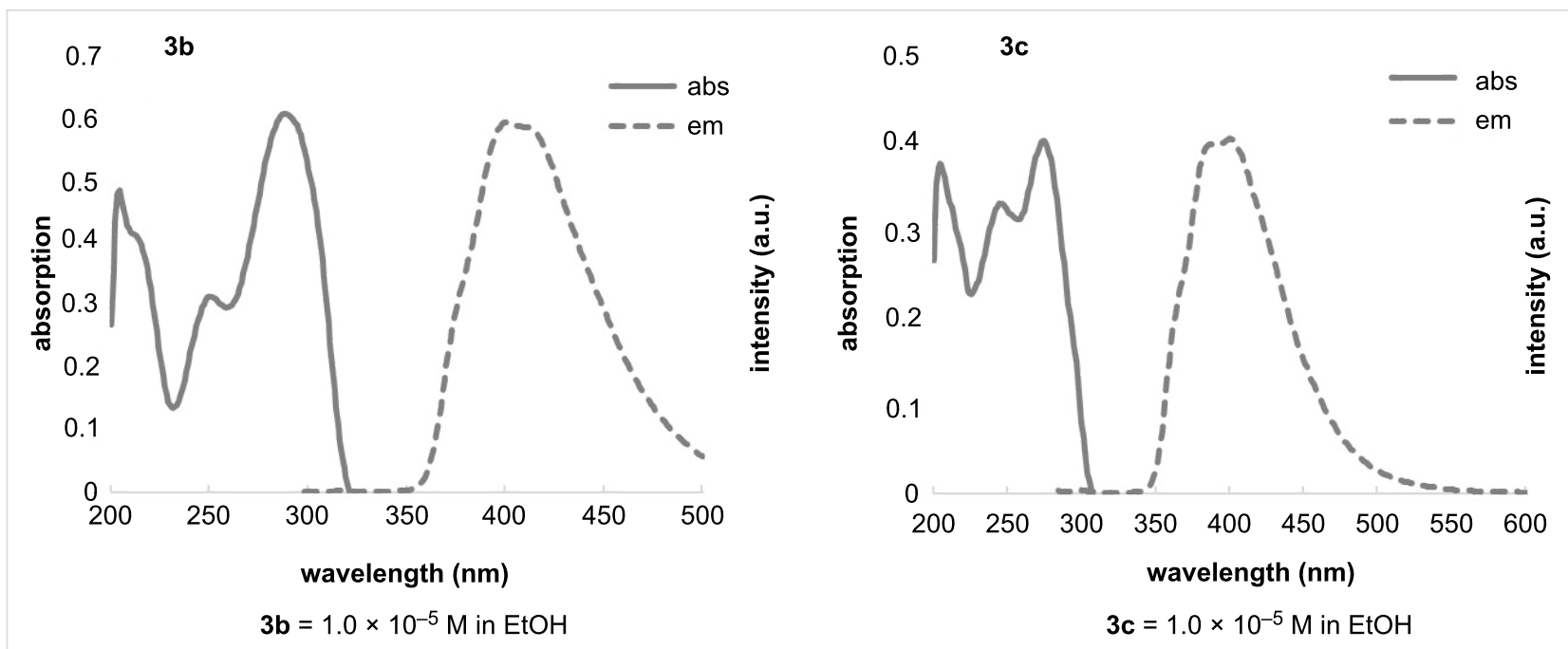

Figure 1: UV-vis and fluorescence (FL) spectra of compounds $\mathbf{3 b}$ and $\mathbf{3 c}$.

Table 1: UV-vis absorption and fluorescence data for 4-fluoroisoxazoles $\mathbf{3 b}$ and $\mathbf{3 c}$, and non-fluorinated compound $\mathbf{2} \mathbf{c}^{\mathrm{a}}$.

\begin{tabular}{lllll} 
dye & $\begin{array}{l}\lambda_{\mathrm{abs}} \\
(\mathrm{nm})\end{array}$ & $\begin{array}{l}\varepsilon \\
\left(\mathrm{M}^{-1} \cdot \mathrm{cm}^{-1}\right)\end{array}$ & $\begin{array}{l}\lambda_{\text {em }} \\
(\mathrm{nm})\end{array}$ & $\begin{array}{l}\text { Stokes shift } \\
\left(\mathrm{cm}^{-1}\right)^{\mathrm{b}}\end{array}$ \\
\hline 3b & 288 & 60476 & 400 & 9722 \\
$3 \mathrm{C}$ & 274 & 40251 & 400 & 11496 \\
2c & 270 & 43015 & 370 & 10010 \\
\hline
\end{tabular}

aMeasurement conditions: $1.0 \times 10^{-5} \mathrm{M}$ in EtOH, excitation at $\lambda=288 \mathrm{~nm}$ for $\mathbf{3 b}, 274 \mathrm{~nm}$ for $\mathbf{3 c}$, and $270 \mathrm{~nm}$ for $2 \mathbf{c}$. b Stokes shift $=1 / \lambda_{\mathrm{ex}}-1 / \lambda_{\mathrm{em}}$ $\left(\mathrm{cm}^{-1}\right)$.

parison with 2c. This observation suggested that the strong electronegativity of fluorine might affect the electron density on the isoxazole ring.

\section{Synthesis of boron ketoiminates and $\alpha$-fluorinated boron ketoiminates}

Boron ketoiminates (BKIs, 6) are one of the new types of boron-chelating dye [34-38], their optical properties feature a large Stokes shift and high molar absorption coefficients $(\varepsilon)$ that are similar to the corresponding boron diketonates. The synthesis and properties of BKIs have been reported recently and they are easily accessible either from the corresponding 1,3-di- ketones $\mathbf{1}$ or from isoxazoles $\mathbf{2}$ through a ring-opening reaction (Scheme 3).

Based on the above observations, we attempted to introduce a fluorine atom into BKIs to access the corresponding $\alpha$-fluorinated boron ketoiminates (F-BKIs, 9). First, we started from 1,3-diketones $\mathbf{1}$ and reacted them with ammonium formate to give the corresponding enaminoketones 5 in high yields (see entries 1-3 in Scheme 4). Then, compounds 5 were treated with 10 equiv of $\mathrm{BF}_{3} \cdot \mathrm{Et}_{2} \mathrm{O}$ in anhydrous THF solution in the presence of an excess of $\mathrm{Et}_{3} \mathrm{~N}$ to give BKIs 6 in moderate yields. However, when the same conditions were applied to the fluori-
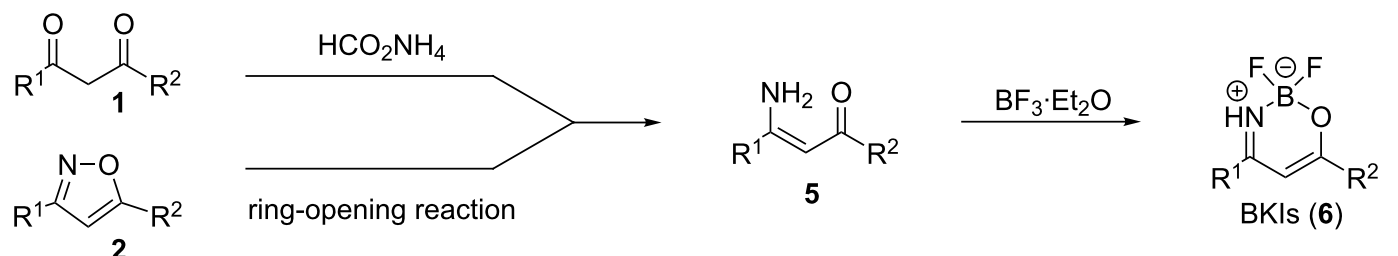


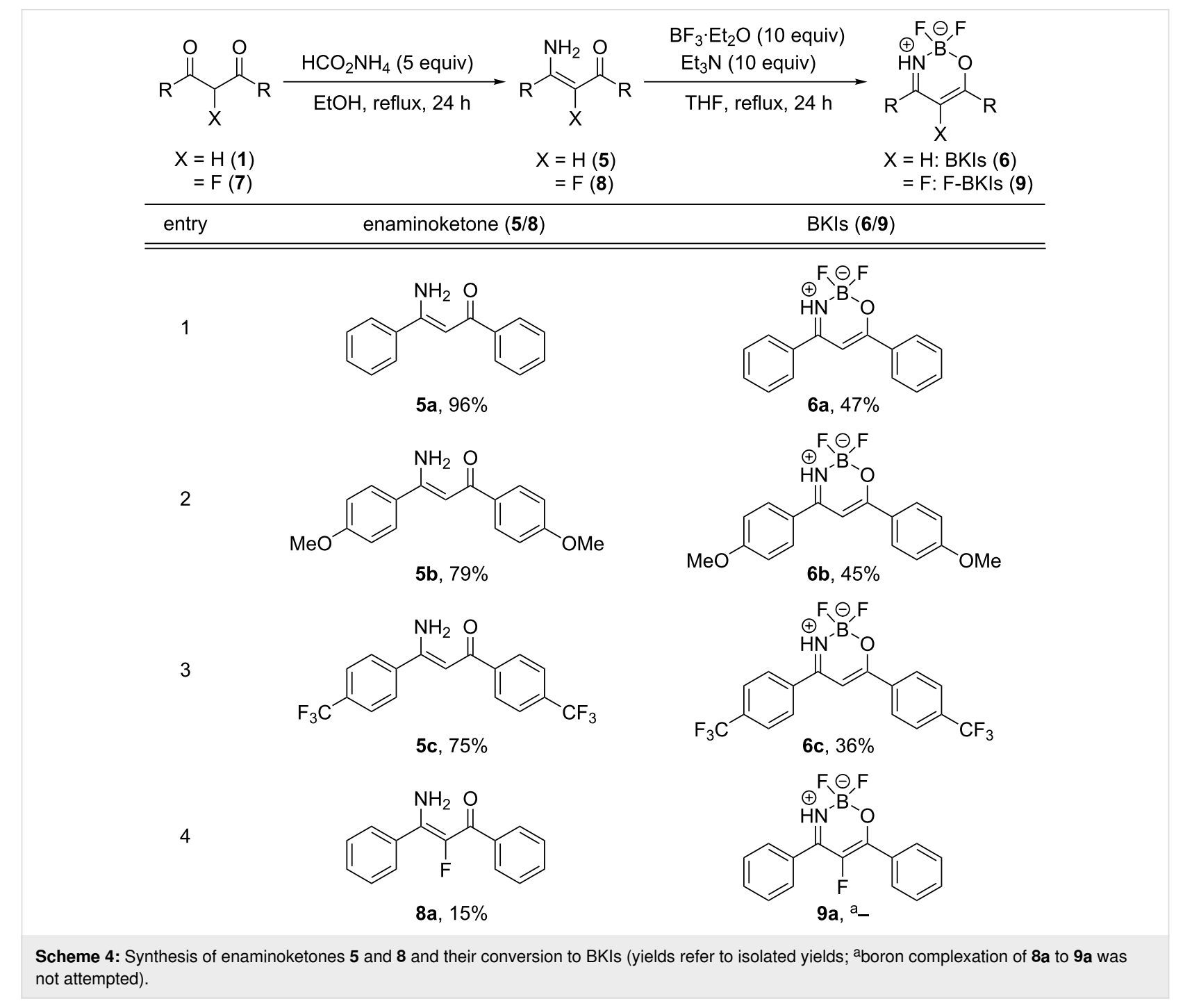

nated diketone, 2-fluoro-1,3-diphenylpropane-1,3-dione (7a), the corresponding enaminoketone 8a was obtained in only low yield (Scheme 4, entry 4) and we did not attempt the conversion of $\mathbf{8 a}$ towards the $\alpha$-fluorinated boron ketoiminate 9a.

Next, we attempted the selective fluorination of $\mathbf{6 b}$ to obtain the desired fluorinated analog $\mathbf{9 b}$. However, in the synthesis of F-BKIs through the selective fluorination of the corresponding
BKIs, the use of 1 equiv of Selectfluor did not give any product and performing the reaction with excess amounts of Selectfluor gave rise to the corresponding $\alpha, \alpha$-difluorinated diketone (Scheme 5).

As an alternative method to synthesize F-BKIs 9, we turned our attention to the ring-opening reaction of isoxazoles. The reductive cleavage of the $\mathrm{N}-\mathrm{O}$ bond in isoxazoles can be achieved by transition metals or their complexes to give the corresponding

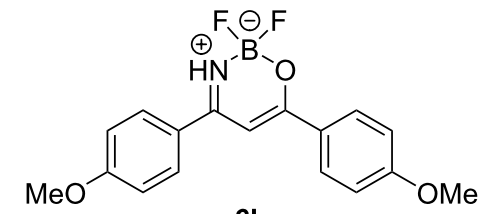

$6 b$

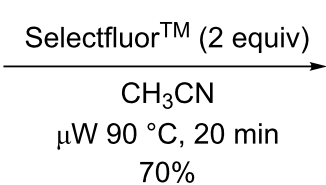

$70 \%$<smiles>COc1ccc(C(=O)C(F)(F)C(=O)c2ccc(OC)cc2)cc1</smiles>

10b 
enaminoketones [35,37]. Consequently, we examined several conditions for the ring opening of fluorinated isoxazoles $\mathbf{3}$, and found that using $\mathrm{Mo}(\mathrm{CO})_{6}$ gave the corresponding $\alpha$-fluorinated enaminoketones $\mathbf{8}$ in moderate yields (Scheme 6). With the enaminoketones $\mathbf{8}$ at hand, the subsequent boron complexation with $\mathrm{BF}_{3} \cdot \mathrm{Et}_{2} \mathrm{O}$ in the presence of $\mathrm{Et}_{3} \mathrm{~N}$ gave the desired F-BKIs 9 in moderate to good yields.

\section{Optical properties of boron ketoiminates and $\alpha$-fluorinated boron ketoiminates}

Chujo and co-workers described that BKIs could be a promising structural motif for having AIE properties [36]. For the purpose of comparison with the photochemical properties of BKIs and F-BKIs, we measured the optical properties of compounds 6 and 9 (Table 2). As shown in Figure 2, the UV-vis absorptions of $\mathbf{6 b}$ and $\mathbf{9 b}$ in THF decreased upon the addition of $\mathrm{H}_{2} \mathrm{O}$, and white precipitates formed in samples exceeding $80 \%$ of water content. Concurrently, the fluorescent luminescence (FL) of the solutions of $\mathbf{6 b}$ and $\mathbf{9 b}$ exhibited an increase in the emission intensities with increasing water content. It was interesting to note that the excitation maximum of $\mathbf{9 b}$ in the aggregated state showed a red-shift by approximately $20 \mathrm{~nm}$ based on the incorporation of a single fluorine atom into the boron ketoiminate scaffold in comparison with $\mathbf{6 b}$. On the other hand, unfortunately, no similar behavior could be observed for the other F-BKIs. This effect of $\mathbf{9 b}$ bearing $\mathrm{OCH}_{3}$ groups on both benzene rings might be attributed to the energy gap between HOMO and LUMO based on the electron-density distribution of boron ketoiminate scaffold induced by the strong electronegative fluorine atom [39]. The FL intensities were lower than that of the corresponding BKIs, a similar tendency to what was also observed in other F-BKIs 9a and 9c. In summary, we found that the F-BKIs described in this report exhibited AIE behavior.

\section{Conclusion}

In conclusion, we demonstrated that 3,5-diaryl-4-fluoroisoxazoles exhibited fluorescent luminescence, although, the emissions were not strong. Interestingly the introduction of a fluorine substituent into the isoxazole scaffold led to an increase in the fluorescent intensity in the aggregated state and exhibited a redshift in the emission intensity. We also achieved the first synthesis of $\alpha$-fluorinated boron ketoiminates (F-BKIs) by the reductive cleavage of the $\mathrm{N}-\mathrm{O}$ bond in 4-fluorinated isoxazoles and demonstrated that F-BKIs exhibited AIE property similarly to their parent BKI. Further structural modifications of compounds $\mathbf{3}$ or $\mathbf{9}$ and applications to fluorescent bioprobes are currently under investigation.

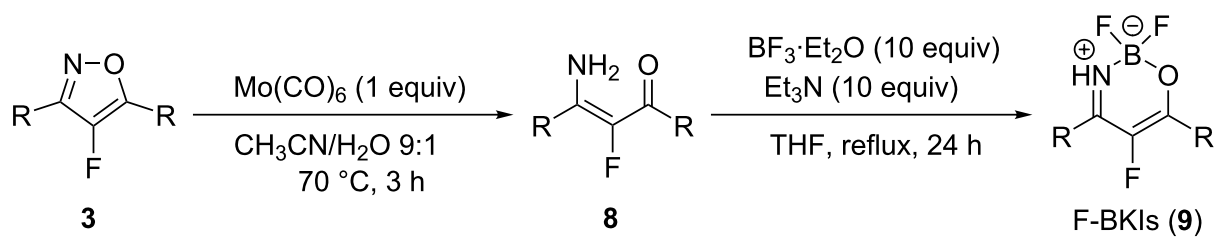

entry $\alpha$-F enaminoketone (8)

$8 a, 61 \%$

2

3

$8 b, 41 \%$<smiles>COc1ccc(C(=O)/C(F)=C(\N)c2ccc(OC)cc2)cc1</smiles><smiles>N/C(=C(/F)C(=O)c1ccc(C(F)(F)F)cc1)c1ccc(C(F)(F)F)cc1</smiles>

$8 c, 41 \%$

$$
\text { F-BKIs (9) }
$$

9a, $79 \%$<smiles>COc1ccc(C2=N[B-](F)(F)OC(c3ccc(OC)cc3)=C2F)cc1</smiles><smiles>O=c1[nH]c(-c2ccc(C(F)(F)F)cc2)c(F)c(-c2ccc(C(F)(F)F)cc2)c1OP(=O)(F)F</smiles>

$9 c, 66 \%$ 
Table 2: Optical properties of BKIs and F-BKIs.

\begin{tabular}{lllll} 
dye & $\begin{array}{l}\lambda_{\text {abs }} \\
(\mathrm{nm})^{\mathrm{a}}\end{array}$ & $\begin{array}{l}\lambda_{\text {ex(agg) }} \\
(\mathrm{nm})^{\mathrm{b}}\end{array}$ & $\begin{array}{l}\lambda_{\text {em(agg) }} \\
(\mathrm{nm})^{\mathrm{b}}\end{array}$ & $\begin{array}{l}\text { Stokes shift } \\
\left(\mathrm{cm}^{-1}\right)^{\mathrm{c}}\end{array}$ \\
\hline 6a & 351 & 352 & 478 & 4489 \\
6b & 365 & 365 & 452 & 5274 \\
6c & 353 & 332 & 517 & 40778 \\
9a & 362 & 365 & 446 & 4976 \\
9b & 378 & 380 & 472 & 5129 \\
$9 \mathbf{9 c}$ & 361 & 366 & 494 & 7080 \\
\hline
\end{tabular}

a Measured in THF solution $\left(1.0 \times 10^{-5} \mathrm{M}\right) .{ }^{\mathrm{b}}$ Measured in THF/ $\mathrm{H}_{2} \mathrm{O} 1: 99$ mixed solvent $\left(1.0 \times 10^{-5} \mathrm{M}\right) .{ }^{\mathrm{c}}$ Stokes shift $=1 / \lambda_{\mathrm{ex}(\mathrm{agg})}-1 / \lambda_{\mathrm{em}}(\mathrm{agg})\left(\mathrm{cm}{ }^{-1}\right)$.
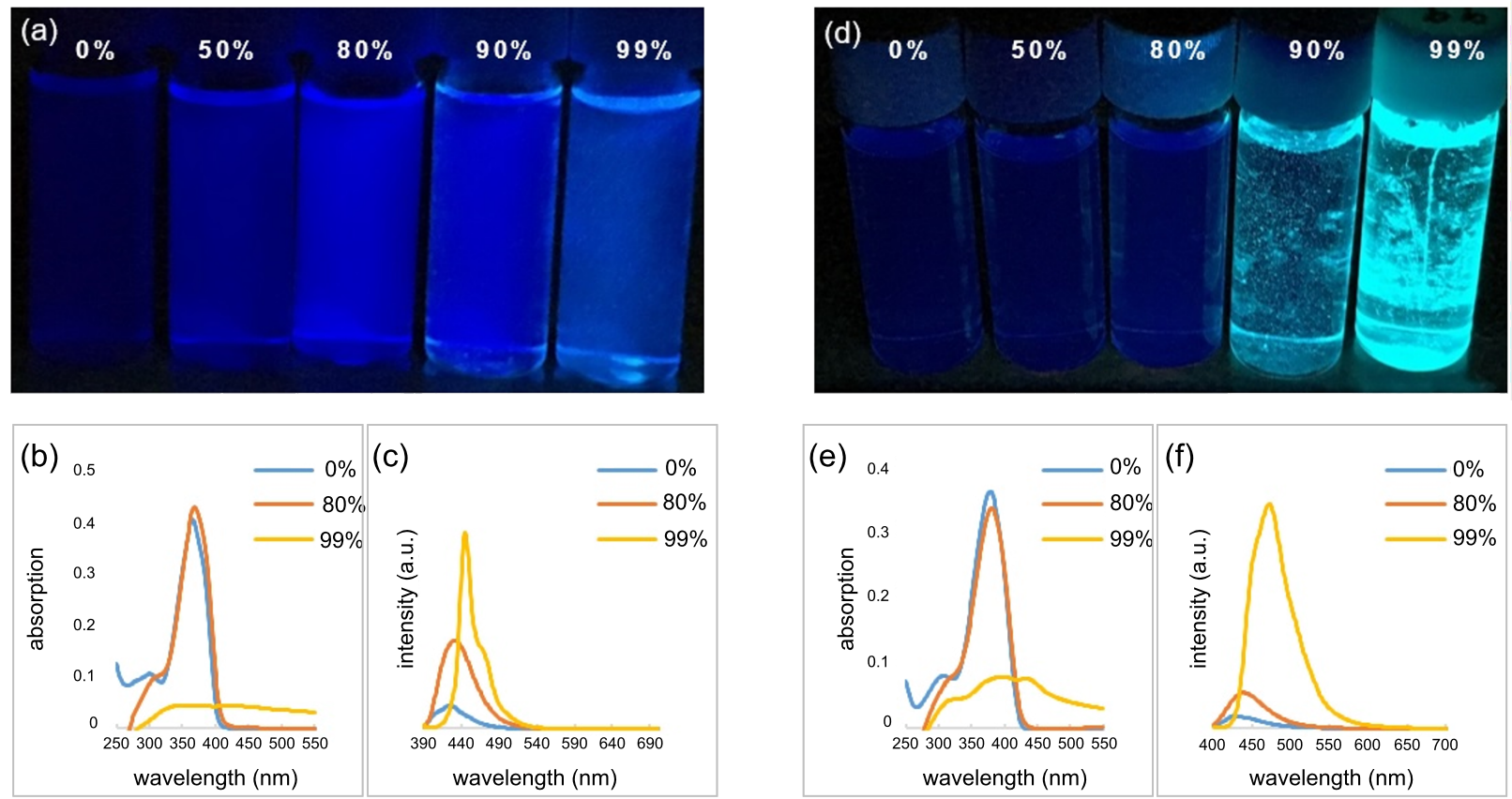

Figure 2: Photochemical properties comparisons of BKIs and F-BKIs. (a-c) BKI 6b: photograph (a), UV-vis (b), and FL (c) spectra at different solvent compositions of THF/ $\mathrm{H}_{2} \mathrm{O}$ upon excitation at $365 \mathrm{~nm}\left(1.0 \times 10^{-5} \mathrm{M}\right) ;(\mathrm{d}-\mathrm{f}) \mathrm{F}-\mathrm{BKI}$ 9b: photograph (d), UV-vis (e), and FL (f) spectra at different solvent compositions of $\mathrm{THF} / \mathrm{H}_{2} \mathrm{O}$ upon excitation at $380 \mathrm{~nm}\left(1.0 \times 10^{-5} \mathrm{M}\right)$.

\section{Supporting Information}

\section{Supporting Information File 1}

General procedures and analytical data, including copies of ${ }^{1} \mathrm{H}$ NMR, ${ }^{13} \mathrm{C}$ NMR and ${ }^{19} \mathrm{~F}$ NMR spectra.

[https://www.beilstein-journals.org/bjoc/content/

supplementary/1860-5397-16-117-S1.pdf]

\section{Acknowledgements}

We wish to acknowledge Professor Dr Kazunori Tsubaki at Kyoto Prefectural University for the measurement of fluorescent luminescence and the useful advice. We also would like to thank Dr. Antal Harsányi at GlaxoSmithKline plc for his helpful comments to improve the quality of the article.

\section{ORCID ${ }^{\circledR}$ iDs}

Kazuyuki Sato - https://orcid.org/0000-0001-6572-602X Yukiko Karuo - https://orcid.org/0000-0002-2106-3399 Masaaki Omote - https://orcid.org/0000-0003-1210-1768

\section{Preprint}

A non-peer-reviewed version of this article has been previously published as a preprint doi:10.3762/bxiv.2020.34.v1 


\section{References}

1. Carter, K. P.; Young, A. M.; Palmer, A. E. Chem. Rev. 2014, 114, 4564-4601. doi:10.1021/cr400546e

2. Guo, Z.; Park, S.; Yoon, J.; Shin, I. Chem. Soc. Rev. 2014, 43, 16-29. doi:10.1039/c3cs60271k

3. Niu, L.-Y.; Chen, Y.-Z.; Zheng, H.-R.; Wu, L.-Z.; Tung, C.-H.; Yang, Q.-Z. Chem. Soc. Rev. 2015, 44, 6143-6160. doi:10.1039/c5cs00152h

4. Liu, H.-W.; Chen, L.; Xu, C.; Li, Z.; Zhang, H.; Zhang, X.-B.; Tan, W. Chem. Soc. Rev. 2018, 47, 7140-7180. doi:10.1039/c7cs00862g

5. Li, H.; Vaughan, J. C. Chem. Rev. 2018, 118, 9412-9454. doi:10.1021/acs.chemrev.7b00767

6. Gao, P.; Pan, W.; Li, N.; Tang, B. Chem. Sci. 2019, 10, 6035-6071. doi:10.1039/c9sc01652j

7. Wang, L.; Frei, M. S.; Salim, A.; Johnsson, K. J. Am. Chem. Soc. 2019, 141, 2770-2781. doi:10.1021/jacs.8b11134

8. Jenekhe, S. A.; Osaheni, J. A. Science 1994, 265, 765-768. doi:10.1126/science.265.5173.765

9. Qian, J.; Tang, B. Z. Chem 2017, 3, 56-91. doi:10.1016/j.chempr.2017.05.010

10. Gu, X.; Kwok, R. T. K.; Lam, J. W. Y.; Tang, B. Z. Biomaterials 2017, 146, 115-135. doi:10.1016/j.biomaterials.2017.09.004

11. Mei, J.; Huang, Y.; Tian, H. ACS Appl. Mater. Interfaces 2018, 10, 12217-12261. doi:10.1021/acsami.7b14343

12. Wang, D.; Tang, B. Z. Acc. Chem. Res. 2019, 52, 2559-2570. doi:10.1021/acs.accounts.9b00305

13. Gao, M.; Tang, B. Z. Coord. Chem. Rev. 2020, 402, 213076. doi:10.1016/j.ccr.2019.213076

14. Niu, G.; Zhang, R.; Shi, X.; Park, H.; Xie, S.; Kwok, R. T. K.; Lam, J. W. Y.; Tang, B. Z. TrAC, Trends Anal. Chem. 2020, 123, 115769. doi:10.1016/j.trac.2019.115769

15. Kuduk, S. D.; DiPardo, R. M.; Bock, M. G. Org. Lett. 2005, 7, 577-579 doi:10.1021/ol047688v

16. Shestopalov, A. M.; Rodinovskaya, L. A.; Fedorov, A. E.; Kalugin, V. E.; Nikishin, K. G.; Shestopalov, A. A.; Gakh, A. A. J. Fluorine Chem. 2009, 130, 236-240. doi:10.1016/j.jluchem.2008.10.005

17. Dubbaka, S. R.; Narreddula, V. R.; Gadde, S.; Mathew, T. Tetrahedron 2014, 70, 9676-9681. doi:10.1016/j.tet.2014.10.055

18. Allen, L. J.; Muhuhi, J. M.; Bland, D. C.; Merzel, R.; Sanford, M. S. J. Org. Chem. 2014, 79, 5827-5833. doi:10.1021/j05003054

19. Xiong, H.; Hoye, A. T.; Fan, K.-H.; Li, X.; Clemens, J.; Horchler, C. L.; Lim, N. C.; Attardo, G. Org. Lett. 2015, 17, 3726-3729. doi:10.1021/acs.orglett.5b01703

20. Katoh, T.; Tomata, Y.; Tsukamoto, T.; Nakada, Y. Tetrahedron Lett 2015, 56, 6043-6046. doi:10.1016/j.tetlet.2015.09.057

21. Lee, H. G.; Milner, P. J.; Buchwald, S. L. J. Am. Chem. Soc. 2014, 136, 3792-3795. doi:10.1021/ja5009739

22. Fier, P. S.; Hartwig, J. F. J. Am. Chem. Soc. 2014, 136, 10139-10147. doi:10.1021/ja5049303

23. Wang, C.; Cai, J.; Zhang, M.; Zhao, X. J. Org. Chem. 2017, 82, 1260-1265. doi:10.1021/acs.joc.6b02624

24. Harsanyi, A.; Conte, A.; Pichon, L.; Rabion, A.; Grenier, S.; Sandford, G. Org. Process Res. Dev. 2017, 21, 273-276. doi:10.1021/acs.oprd.6b00420

25. Marque, S.; Snoussi, H.; Loupy, A.; Plé, N.; Turck, A. J. Fluorine Chem. 2004, 125, 1847-1851. doi:10.1016/j.jfluchem.2004.06.016

26. Ryan, S. J.; Schimler, S. D.; Bland, D. C.; Sanford, M. S. Org. Lett. 2015, 17, 1866-1869. doi:10.1021/acs.orglett.5b00538
27. Schimler, S. D.; Ryan, S. J.; Bland, D. C.; Anderson, J. E.; Sanford, M. S. J. Org. Chem. 2015, 80, 12137-12145. doi:10.1021/acs.joc.5b02075

28. Sloop, J. C.; Jackson, J. L.; Schmidt, R. D. Heteroat. Chem. 2009, 20, 341-345. doi:10.1002/hc.20556

29. Qian, J.; Liu, Y.; Zhu, J.; Jiang, B.; Xu, Z. Org. Lett. 2011, 13, 4220-4223. doi:10.1021/ol201555z

30. Stephens, C. E.; Blake, J. A. J. Fluorine Chem. 2004, 125, 1939-1945. doi:10.1016/j.jfluchem.2004.08.001

31. Campbell, T. F.; Stephens, C. E. J. Fluorine Chem. 2006, 127, 1591-1594. doi:10.1016/j.jfluchem.2006.08.007

32. Hatfield, J. M.; Eidell, C. K.; Stephens, C. E. Tetrahedron Lett. 2013, 54, 1025-1028. doi:10.1016/j.tetlet.2012.12.052

33. Sato, K.; Sandford, G.; Shimizu, K.; Akiyama, S.; Lancashire, M. J.; Yufit, D. S.; Tarui, A.; Omote, M.; Kumadaki, I.; Harusawa, S.; Ando, A. Tetrahedron 2016, 72, 1690-1698. doi:10.1016/j.tet.2016.02.026

34. Macedo, F. P.; Gwengo, C.; Lindeman, S. V.; Smith, M. D.; Gardinier, J. R. Eur. J. Inorg. Chem. 2008, 3200-3211. doi:10.1002/ejic.200800243

35. Koyama, Y.; Matsumura, T.; Yui, T.; Ishitani, O.; Takata, T. Org. Lett. 2013, 15, 4686-4689. doi:10.1021/ol401984j

36. Yoshii, R.; Nagai, A.; Tanaka, K.; Chujo, Y. Chem. - Eur. J. 2013, 19 , 4506-4512. doi:10.1002/chem.201203703

37. Minuti, L. F.; Memeo, M. G.; Crespi, S.; Quadrelli, P. Eur. J. Org. Chem. 2016, 821-829. doi:10.1002/ejoc.201501478

38. Dohe, J.; Koßmann, J.; Müller, T. J. J. Dyes Pigm. 2018, 157 , 198-217. doi:10.1016/j.dyepig.2018.05.001

39. Yamada, S.; Morita, M.; Konno, T. J. Fluorine Chem. 2017, 202, 54-64. doi:10.1016/j.jfluchem.2017.09.003

\section{License and Terms}

This is an Open Access article under the terms of the Creative Commons Attribution License (http://creativecommons.org/licenses/by/4.0). Please note that the reuse, redistribution and reproduction in particular requires that the authors and source are credited.

The license is subject to the Beilstein Journal of Organic Chemistry terms and conditions: (https://www.beilstein-journals.org/bjoc)

The definitive version of this article is the electronic one which can be found at: doi:10.3762/bjoc. 16.117 